\title{
A kis téliaraszoló (Operophtera brumata L.) aktivitásának modellezése abiotikus paraméterekkel
}

\author{
Zsuzsanna Kúti, Anikó Hirka, Gergely Petrányi, Csaba Szabóky, László Gimesi, Levente Hufnagel, \\ Márta Ladányi ${ }^{1}$,
}

\begin{tabular}{|c|c|}
\hline I N F O & A B S T R A C T \\
\hline Received 9 April 2010 & \\
\hline Accepted 19 May 2010 & In this paper the Hungarian light trap data (1973-93) of Operophtera brumata, L., an \\
\hline Available on-line 31 May 2010 & important pest in forestry and horticulture are analysed. The life cycle of the Lepidoptera \\
\hline Responsible Editor: K. Rajkai & $\begin{array}{l}\text { is introduced and the activity of the pests is estimated. We prove that the gradation of the } \\
\text { pests has the same periodicity as sunspot cycle has, the gradation peak as feedback is }\end{array}$ \\
\hline Keywords: & delayed by about two years. The population dynamics of the pest is defined also by \\
\hline $\begin{array}{l}\text { Operophtera brumata, sunspot } \\
\text { cycle, climatic indicators, } \\
\text { regression model, light trap }\end{array}$ & $\begin{array}{l}\text { climatic parameters. The most effective climatic parameters in this time slice were the } \\
\text { sum of precipitation in June and the sum of sunny hours in October. The model is } \\
\text { analysed, the model diagnostics is given and an outlook is described on the planned future } \\
\text { research, development and application. }\end{array}$ \\
\hline
\end{tabular}

\section{N F O}

Beérkezés 2010 Április 9. Elfogadás 2010 Május 19. On-line elérés 2010 Május 31. Felelős szerkesztö: Rajkai K

\section{Kulcsszavak:}

Operophtera brumata, L., napfolt ciklus, meteorológiai indikátorok, regressziós modell, fénycsapda

\section{ÖS S Z E F O G L A L Ó}

A kis téliaraszoló (Operophtera brumata L.) 1973 és 1993 közötti magyarországi fénycsapda adatai alapján becsüljük az erdészeti és kertészeti szempontból is fontos szerepet játszó kártevő éves aktivitását. Bemutatjuk a kártevő életciklusát és igazoljuk, hogy a Lepidoptera faj gradációja a napfolttevékenység ciklusaival azonos hosszúságú ciklusokból áll, valamint a napfolt ciklusokra néhány éves késéssel gradációs csúccsal felel. A kártevő populációdinamikáját ezen kívül különböző meteorológiai tényezők is befolyásolják. A vizsgált időszakban a legmeghatározóbb klimatikus paraméter a júniusi csapadékösszeg, valamint az októberi napsütéses órák számának összege. A közelítő modellünket elemezzük, a modell diagnosztikáját közöljük, továbbá kitekintést nyújtunk a további általánosítás, fejlesztés és alkalmazás lehetőségeire.

\section{Bevezetés}

A klímaváltozás globális környezeti probléma, ami mára központi kérdéssé vált. Nemzetközi adatok szerint 1950 és 2003 között a Föld felszínének átlaghőmérséklete $13,87{ }^{\circ} \mathrm{C}$-ról 14,52 ${ }^{\circ} \mathrm{C}$-ra növekedett. A globális felmelegedés következménye a szélsőséges meteorológiai események számának és intenzitásának növekedése, ami a globális és regionális klíma megváltozását egyaránt eredményezheti (VAHAVA, 2006). Fokozatosan növekvő időskálán a földrajzi és meteorológiai jelenségek mellett többek között csillagászati jelenségek - például a megközelítően 11 éves napfoltciklus (fler), többletsugárzást okozva - is hatnak a Föld hőmérsékletére, valamint a rovarok populációdinamikájára. Kérdéses, hogy a rovarok közül a mezögazdasági és erdészeti kártevőkre milyen hatással lehetnek ezek a tényezők maguk, illetve ezen tényezők változásai. Hazai kutatók évek óta foglalkoznak a kis téliaraszoló fénycsapdázásának eredményességének vizsgálatával időjárási frontok alkalmával (Puskás \& Nowinszky 1998; 2008, Nowinszky \& Puskás, 1998, Nowinszky et al., 2008), és a Péczely-féle makroszinoptikus helyzetek idején (Nowinszky \& Puskás 2002). A klimatikus paraméterek múltbeli és várható hatásait az élő gerinctelen közösségekre az utóbbi években számos kutató vizsgálta Drégelyi-Kiss et al., 2008, 2009, Sipkay et al., 2008, 2009, Diós et al., 2009). Dolgozatunkban egy tömeges erdészeti és kertészeti kártevő Lepidoptera faj, a kis téliaraszoló (Operophtera brumata Linnaeus, 1758) aktivitását vizsgáljuk a napfoltciklus, valamint meteorológiai

\footnotetext{
${ }^{1}$ Márta Ladányi

Corvinus University of Budapest 1118 Budapest, Villányi út 29-43.,Hungary

marta.ladanyi@uni-corvinus.hu
} 
paraméterek függvényében. E faj egyike a legrégebben ismert és időnként tömegesen előforduló erdészeti, illetve gyümölcsfakártevőknek, ezért populációdinamikai vizsgálata kiemelt jelentőségü.

\section{Anyag és módszerek}

\subsection{A vizsgálatban felhasznált adatok}

A vizsgálatba a rendelkezésre álló harmincegy év adatai helyett csupán huszonegy év (1973-1993) 252 hónapjának fénycsapda és meteorológiai adatait vontuk be, mert csak ebben az időszakban volt az adatfelvétel egységesnek tekinthető.

A fénycsapda adatok az Országos Növényvédelmi és Erdészeti Fénycsapdahálózat erdészeti adatbázisából származnak. A 63941 befogott hím egyed adata az alábbi kilenc erdészeti fénycsapdaállomásról való: Felsőtárkány, Gerla-Gyula, Mátraháza, Répáshuta, Sopron, Szentpéterfölde, Tolna, Tompa, Várgesztes.

A rovarökológiai kutatásoknál a legelterjedtebben alkalmazott gyüjtőeszközök az attraktív csapdák, ezek közül is a fénycsapdák, amelyek az éjjel aktív rovarokra csalogató hatást fejtenek ki. A gyüjteni kívánt rovarcsoporttól, a terület klimatikus viszonyaitól és a feldolgozás céljától függően, a fénycsapdázással foglalkozó kutatók számos fénycsapda típust fejlesztettek ki. A fénycsapdák lényege, hogy valamennyi csapdához valamilyen mesterséges fényforrás csalogatja oda a rovarokat. A legegyszerübb fénycsapdák gyüjtő illetve ölőszerkezettel nem is rendelkeznek, több fénycsapda típusnál a rovarok megölését elektromos árammal végzik. A fénycsapdákban többféle ölőanyagot használnak. Gyakoriak a klórozott szénhidrogének, mint tetraklór-etilén, triklór-etilén, tetraklór-etán, valamint egyéb veszélyes mérgek: kálium-cianid, nátrium-cianid NOWINSZKY (2003).

A fénycsapda hálózat kiépítését 1960-as évek elején a Mezőgazdasági és Élelmezésügyi Minisztérium Növényvédelmi Szolgálata rendelte el országosan. Az összesen mintegy 150 fénycsapda most már több mint 40 éven keresztül szolgáltat adatokat a rajzásfenológia, a rovarökológia kutatói számára HERCZIG (1983). Az országos hálózat hatalmas mennyiségü és felbecsülhetetlen tudományos értékủ adatot szolgáltatott entomológiai kutatások részére. A Jermy-típusú fénycsapda (1. ábra) terelőlemez nélküli, fényforrása 2 m magasságban elhelyezett $100 \mathrm{~W}$-os normál égő, színhőmérséklete $2900{ }^{\circ} \mathrm{K}$, az ölőanyaga kloroform. A növényvédelmi csapdák április 1-től október 31-ig, minden este 18 órától hajnali 4 óráig (UT) üzemelnek, míg az erdészeti fénycsapdák éppen a téli araszolók rajzásának követése érdekében a fagyos időszak kivételével a tél beálltáig gyüjtenek.

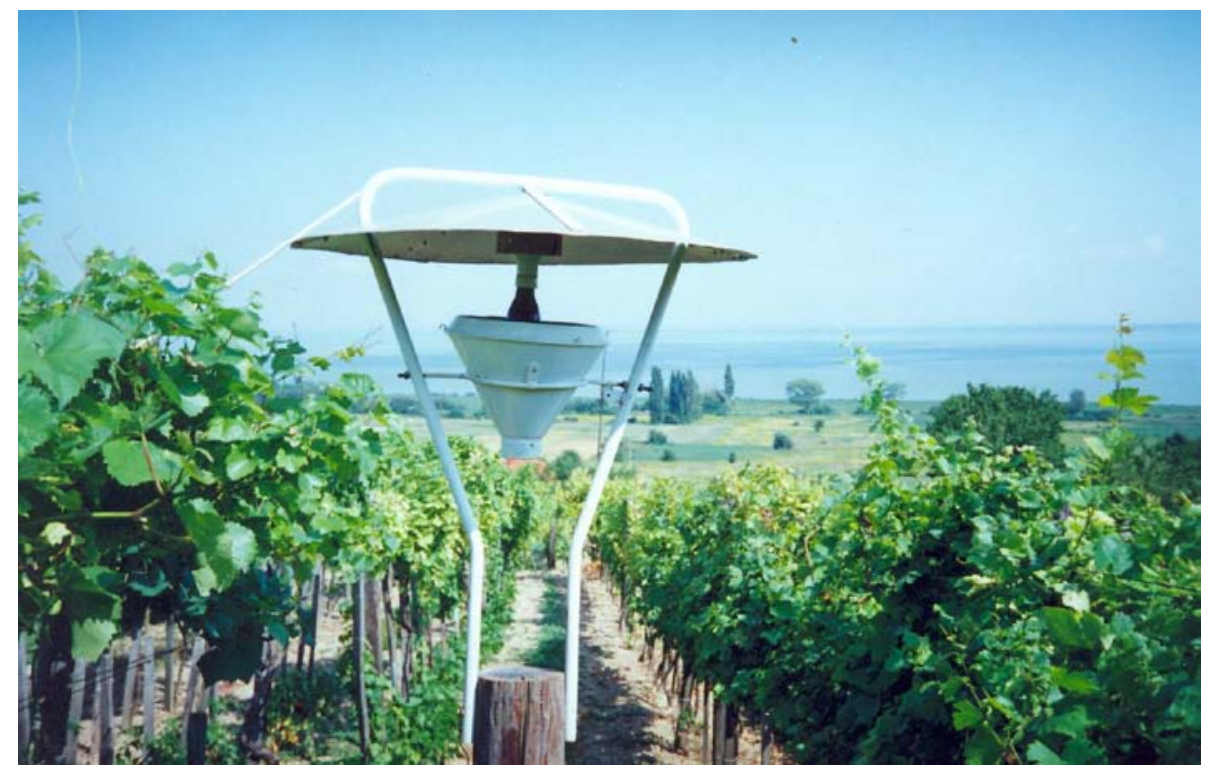

1. ábra. A Jermy-típusú fénycsapda (fotó: Kúti Zs.) 
A meteorológiai adatok a Budapesti Corvinus Egyetem Kertészettudományi Kar Matematika és Informatika Tanszékének AIIR (Agroökológiai Integrált Információs Rendszer) adatbázisából származnak, a meteorológiai állomások közül egy - Budapest (mint kiemelt) - állomás napi adataival dolgoztunk. A napi értékek az adatbázisban a csapadékmennyiséget, a középhőmérsékletet, a napfényes órák számát és a relatív páratartalmat tartalmazzák.

A fénycsapdahálózatból a lepkék rendjének az egyik legnagyobb fajszámú családjába tartozó tömeges erdészeti és kertészeti kártevő Lepidoptera fajt, az araszolólepkék (Geometridae) egyik leggyakoribb hazai képviselöjét, a kis téliaraszolót (Operophtera brumata) választottuk.

\subsection{Az Operophtera brumata jellemzése}

Az Operophtera brumata egynemzedékes, egész Európában, Transz-Kaukázusban és KeletÁzsiában elterjedt közönséges faj, Euroszibériai faunaelem. Észak-Amerikába is behurcolták, ahol mára már szintén jelentős lombrágóként tartják nyilván. A síkságtól a magashegységig mindenütt megtalálható. Polifág, igen sok tápnövényét ismerjük (Szabóky, Csóka, 2008).

$\mathrm{Az}$ ősszel és télen lerakott peték áttelelnek. Tavasszal időjárástól függően március elejétől, közepétől kelnek ki a még sötét testü és fekete fejü hernyók. A hernyók kikelése rendszerint egybeesik a lombos fák fakadásával. A petéből kikelő hernyók eleinte a fakadó rügyeket károsítják, ilyenkor teljesen berágják magukat a rügyekbe, később a virágbimbókat, és a virágokat rágják. Lombfakadás után a levélcsomókat lazán összeszövik, a rágás mindig összefont levelek között történik, a leveleket lyuggatják, vagy karéjosan rágják. Egy hernyó tápanyag szükséglete $40-50 \mathrm{~cm}^{2}$ levélfelület. A hernyók főleg éjjel rágnak. Időjárástól függően 25-40 nap alatt fejlődnek ki (Tóth, 1999), ezalatt 5 fejlődési fokozaton haladnak végig. Május első felében kezdenek távozni a fákról, ahol május közepén már csak a parazitált hernyók találhatók. A kifejlett hernyó mérete 25-30 mm (Csóka, 1995), amelyek a fákról selyemszálon leereszkednek, vagy a törzsön lemásznak, és a talaj felszínén (47,2 \%) vagy a talaj legfelső 3-8 cm-es rétegében (52,8 \%) kemény falú gubót szőve bábozódnak be. A bábok a korona védőlombja alatt koncentrálódnak, a bábozódás mélysége a talaj tulajdonságaitól és az aljnövényzettől függ, kötött talajon $2 \mathrm{~cm}$, homoktalajon $6 \mathrm{~cm}$ mélyen. A nyarat bábállapotban diapauzában töltik, majd októbertől január elejéig rajzanak. A bábból való kikeléshez rendszerint egy nagyobb, áztató jellegü őszi eső szükséges. A bábokból az első fagyok után kelnek ki a lepkék. A lepkék kikeléséhez nagyobb csapadék és megfelelő hőmérséklet szükséges (fagymentes időszak). A lepke általában október végén jelenik meg.

A hímek rendszeresen pár nappal korábban jelennek meg, mint az apró szárnycsökevényt viselő nőstények. Napközben az avaron vagy a fatörzsön ülve pihennek. A hímek az őszi napnyugtától (kb. 16 órától) kezdve repkednek a lomb nélküli fák között. A rajzása hóesésben is folyamatosan tart, csak az egybefüggő vastag hótakaró és az erős fagyok jelentenek akadályt (Szőcs, 1976). A rajzás 6-8 hétig tart. Erős november eleji fagy és hótakaró esetén a rajzás szünetel, de felmelegedés után decemberben, sőt gyakran még januárban folytatódik. A repülés optimális hőmérséklete 5-10 ${ }^{\circ} \mathrm{C}$. A lepkék napközben kelnek ki, a hímek aktivitása naplemente után kezdődik és kb. éjfélig tart. A hímek a mesterséges fényt tömegesen keresik fel, alacsony légnyomás esetén a rajzás intenzitása sokszorosára nő. A szárnycsonkos nőstények éjjeli és kora reggeli órákban hagyják el a bábokat, gyalogolva igyekeznek a legközelebbi fatörzshöz, amelyen felfelé haladva a koronába jutnak. A hímek a fa törzse körül repkednek, és ott keresik fel a törzsön felfelé mászó vagy még az avarlevelek között lévő röpképtelen nőstényeket és megindul a párzásuk. A kopula több óráig tart, utána a hím 2-3, a nőstény 8-9 napig él (Győrffi, 1957). Egy-egy nőstény által lerakott peték száma 200-300 is lehet. Felfelé ívelő gradáció esetében ez a peteszám 450-500-ig emelkedhet, majd a gradáció összeomlása után ismét az alacsonyabb értékre száll vissza. (Jermy, Balázs, 1993). A megtermékenyített nőstények a fák koronájában általában a rügyek közelében, a rügypikkelyek közé helyezik el petéiket egyesével, vagy 2-3 petéböl álló kisebb csoportokban.

A hosszú meleg ősz ismétlődő esőkkel elösegíti az elszaporodásukat. A lepkék rajzása szempontjából fontos, hogy az esti órákban kedvező meleg és kissé csapadékos időjárási körülmények uralkodjanak. Ezzel szemben előnytelen számára a hideg, csapadékos tavasz. A késő tavaszi fagyok pedig jelentős lárvapusztulást okozhatnak. A tömegszaporodást és a rajzásmenetet is jól jelzi a

Zsuzsanna Kúti, Anikó Hirka, Gergely Petrányi, Csaba Szabóky, László Gimesi, Levente Hufnagel, Márta Ladányi: A kis téliaraszoló (Operophtera brumata L.) aktivitásának modellezése abiotikus paraméterekkel 
fénycsapdákra szívesen repülő szárnyas hímek egyedszámának fokozatos növekedése. Rajzásuk erdőben 5-7 nappal korábban kulminál, mint gyümölcsösökben (Kovács, 1962). A gradációja nagyon intenzív és ciklikus, viszonylag rövid ideig tart (Schwerdtfeger, 1969). Nálunk a gradációja 3-5 évig tart (Szontagh, 1980). A fénycsapda adatok szerint tömegszaporodása 10-11 évenként ismétlődik. Az araszolók okozta tarrágásokban az Operophtera brumata domináns faj, általában tölgyesekben, gyertyános-tölgyesekben szaporodik el tömegesen, gyümölcsösökben is jelentős károkat okozhat. Tömegszaporodását a meleg száraz tavaszi időjárás segíti elő, a hideg esős tavaszi időjárás gátolja a szaporodását és a gradáció összeomlását eredményezi (Szontagh, 1980).

Magyarországon 1962-től 4 tömegszaporodási ciklusa volt. Gradáció csúcsai 1961, 1971-72, 1982, 1992 (Tóth, 1999).

\subsection{A vizsgálat módszere}

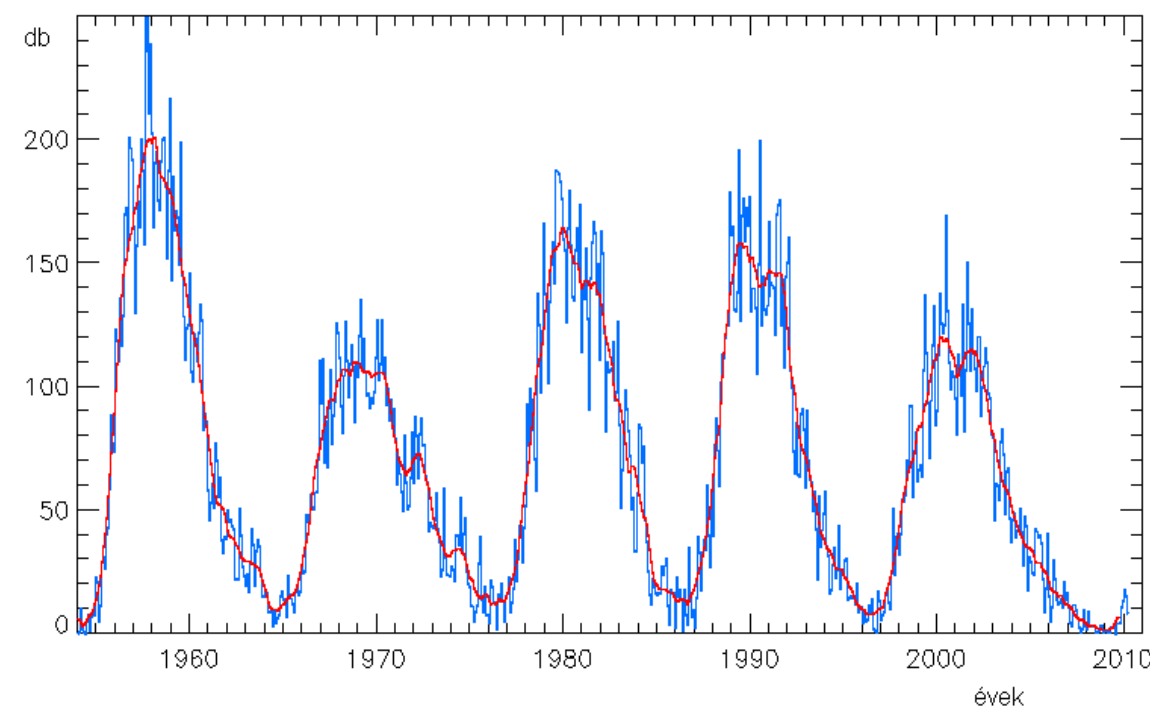

2. ábra. Napfolt ciklusok (1950-2010), a havi relatív napfoltszámok (kékkel) és a simított adatsor (pirossal) a Sunspot Index Data Center (SIDC) nyílt adatbázisából származnak.

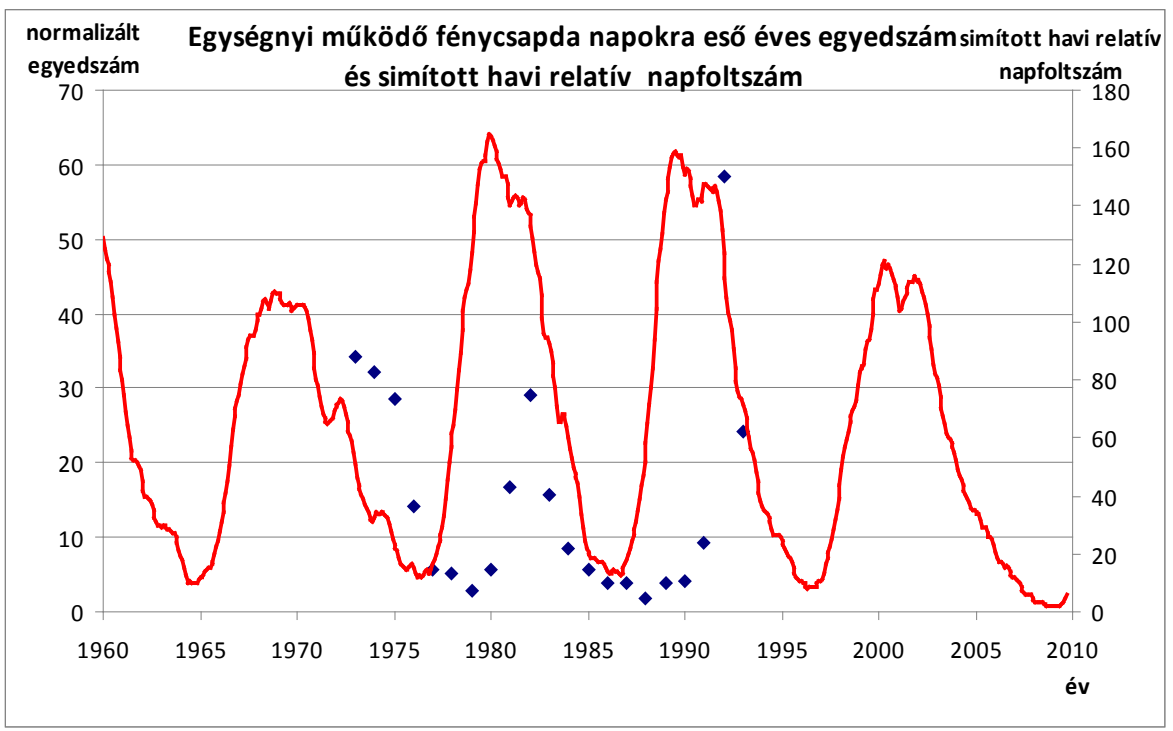

3. ábra. Egységnyi müködő fénycsapda napokra eső egyedszám

(1963-2006, kékkel, bal tengelyen, az adatfelvétel csupán 1973-1993-ig tekinthető egységesnek), valamint a simított havi relatív napfoltszámok (pirossal, jobb tengelyen, a simított adatsor a Sunspot

Zsuzsanna Kúti, Anikó Hirka, Gergely Petrányi, Csaba Szabóky, László Gimesi, Levente Hufnagel, Márta Ladányi: A kis téliaraszoló (Operophtera brumata L.) aktivitásának modellezése abiotikus paraméterekkel 
Index Data Center nyílt adatbázisából származik). Magyarországon 1961-től 4 tömegszaporodási ciklus figyelhető meg. A gradáció csúcsai: 1961, 1971-72, 1982, 1992, melyek minden ezek közül minden alkalommal a napfoltciklusok déli komponensének a közepére estek.

A rendelkezésre álló fénycsapdahálózati adatokból működő fénycsapda napokra eső (normalizált) egyedszámot számoltunk, ezzel a különböző évekre vonatkozó adatokat összehasonlíthatóvá tettük. Nowinszky (2000) szerint az egyedszám évekre vonatkoztatott, a napfolttevékenységgel azonos periódusú ciklikusságot mutat (2. ábra). A gradáció csúcsai a napfolttevékenység déli komponenseinek a közepén helyezkednek el (3. ábra). Ezért a müködő fénycsapda napokra eső egyedszámra 21 éves, $A^{*}(x-B)^{2}+C$ alakban felírható (másodfokú) ciklusos modellt illesztettünk $(x=1,2, \ldots, 11$, az 1973. évben $x=2$ ). A ciklust a modell változójának és a $B=6$ paraméter segítségével 11 évben rögzítettük, mert éves adatokkal dolgozva a törtszámú ciklus nem értelmezhető. A legkisebb négyzetek elve alapján optimalizálva az együtthatókra $A=0,9164, C=6,425$ adódott $\left(\mathrm{R}^{2}=0,311\right.$, $\mathrm{F}=73,5)$.

A modellt meteorológiai indikátorok bevezetésével kívántuk javítani.

A napi adatokból képeztük minden hónapra a havi hőmérséklet- és csapadékösszegeket, illetve átlagokat. Ugyanígy a napfényes órák számára és a relatív páratartalomra is előállítottuk a megfelelő havi összeg- valamint átlagindikátorokat. A többváltozós lineáris regressziót stepwise módszerrel, az SPSS 17 programmal végeztük, ennek segítségével határoztuk meg a müködő fénycsapda napokra eső (normalizált) egyedszámot leginkább meghatározó indikátort, végül regressziós diagnosztikát végeztünk.

\section{Eredmények}

A stepwise módszer a ciklikus modellen kívül a június havi csapadék összegét, valamint az októberi napfényes órák számának összegét válogatta be a modellbe (1. táblázat). Az R2=0,689-re növekedett, a modellre vonatkozó ANOVA F értéke 12,55 (Sig.=0,000) lett. Az együtthatók becslésére vonatkozó t-próbák számított értékei a ciklikus modellre, a konstansra, a júniusi és az októberi indikátorra mint változókra az alábbiak: 2,67; 2,50; 2,81; -4,26 (Sig.= 0,016; 0,023; 0,012; 0,001). Az indikátorokkal bővített modell standard hibája 144,16-ról 60,24-re csökkent a ciklikus modelléhez képest (4. ábra).

1. táblázat. A ciklikus modellt és a meteorológiai paramétereket tartalmazó modell együtthatói és az együtthatókra vonatkozó regressziós diagnosztika eredményei

\begin{tabular}{|c|c|c|c|c|c|c|c|}
\hline \multirow[b]{2}{*}{ Model } & \multicolumn{2}{|c|}{$\begin{array}{l}\text { Nemstandardizált } \\
\text { együtthatók }\end{array}$} & \multirow{2}{*}{$\begin{array}{c}\begin{array}{c}\text { Standardizált } \\
\text { együtthatók }\end{array} \\
\text { Beta }\end{array}$} & \multirow[b]{2}{*}{$\mathrm{t}$} & \multirow[b]{2}{*}{ Szign. szint } & \multicolumn{2}{|c|}{ Kollinearitás } \\
\hline & B & Std. Hiba & & & & Tolerancia & $\begin{array}{l}\text { Tolerancia } \\
\text { reciproka }\end{array}$ \\
\hline Konstans & 27,673 & 11,045 & & 2,505 & ,023 & & \\
\hline jún. csap.össz. & ,250 & ,089 & ,393 & 2,819 & ,012 & ,940 & 1,063 \\
\hline okt. napf. órák össz. &,- 257 & ,060 &,- 623 & $-4,263$ & ,001 & ,857 & 1,167 \\
\hline ciklikus modell & ,714 & ,267 & ,380 & 2,674 & ,016 & ,904 & 1,106 \\
\hline
\end{tabular}

Függő változó: éves normalizált egyedszám (1973-93)

A ciklikus modell magyarázat lehet arra, hogy a lepke gradációjának ciklusossága megegyezik a naptevékenység 10-11 éves ciklusával. Ennél a fajnál a naptevékenység pozitív módon befolyásolja az aktivitást. A gradáció csúcsok egy, illetve két évvel később követik a naptevékenység görbéinek csúcsait, ez természetszerủ, hiszen az egynemzedékes fajok egyedeinek a környezeti változásokra adott visszacsatolásai elhúzódó jellegüek. 


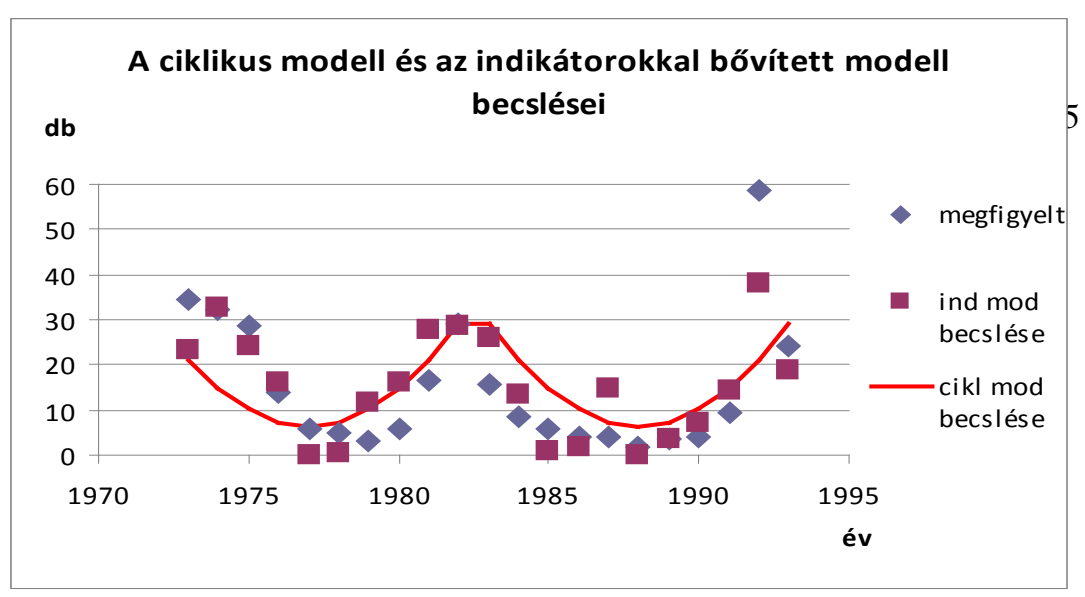

4. ábra. A (másodfokú) ciklikus modell és az indikátorokkal bővített modell becslései (1973-1993)

A hernyók júniusban fejezik be fejlődésüket, ekkor indulnak el a lombkoronából a talaj felé bábozódni. A csapadék következtében a talaj nedvességtartalma nő, így a vizes talaj lehetővé teszi, hogy a fejlett hernyók nagyobb százaléka sikeresen bábozódjon. Ez indokolja a júniusi csapadékösszeg meghatározó szerepét.

Az októberi napfényes órák összege negatív együtthatóval szerepel a modellben. A többnyire október végén kikelő lepkéknek a kikelést megelözően fagyra van szükségük. Amennyiben az október napos, meleg, és a fagy későn következik be, ezt követően általában rövidebb a repülésnek kedvező (5-10 ํC-os napi középhőmérsékletü) időszak, ami a fogások sikerességét gátolja.

\section{Kitekintés}

Modellünket a továbbiakban hosszabb idősorra és más Lepidoptera fajokra is kiterjesztjük. A hosszabb idősorok vizsgálatánál gondot jelent, hogy a felvételezés nem volt egységes az elmúlt évszázad második felében, ami az összehasonlíthatóságot nehezíti. Előzetes vizsgálataink alapján sejtésünk, hogy a klimatikus viszonyok változása okozhatja, hogy egyes időszakokban más-más meghatározó meteorológiai paramétert kell bevonni a modellbe. Ezek a paraméterek az évek klimatikus karakterét is jellemezhetik. A modellben szereplő paraméterek megváltozásának leírása a klimatikus jelleg indikátor-típusú jellemzését alapozhatja meg. A modellek regionális klímamodellek becsléseivel futtatva a különbözö fajok populációdinamikai válaszadásának sztochasztikus modellalapú elörejelzésére lehetnek alkalmasak.

\section{Köszönetnyilvánítás}

Köszönetünket fejezzük ki Prof. Mészáros Zoltánnak, a mezőgazdasági tudomány doktorának, önzetlen és hasznos szakmai tanácsaiért és segítségéért. Köszönet illeti a bírálókat is, akik aprólékos figyelemmel olvasták végig dolgozatunkat, és hasznos megjegyzésekkel és tanácsokkal láttak el minket.

\section{Hivatkozások}

A globális klímaváltozás: hazai hatások és válaszok. 2006. KvVM-MTA “VAHAVA” projekt összefoglalása, Budapest

Csóka, Gy. 1995. Lepkehernyók. Budapest. Agroinform Kiadó és Nyomda Kft.

Diós, N., Szenteleki, K., Ferenczy, A., Petrányi, G., Hufnagel, L. 2009. A Climate profile indicator based comparative analysis of climate change scenarios with regard to maize (Zea mays L.) cultures - Applied Ecology and Environmental Research, 7(3): 199-214.

Drégelyi-Kiss, Á., Drégelyi-Kiss, G., Hufnagel, L. 2008. Ecosystems As Climate Controllers - Biotic Feedbacks - Applied Ecology And Environmental Research, 6(2):111-134. 
Drégelyi-Kiss, Á., Hufnagel, L. 2009. Simulations Of Theoretical Ecosystem Growth Model (Tegm) During arious Climate Conditions - Applied Ecology And Environmental Research, 7(1): 71-78.

Győrffi, J. 1957. Erdészeti rovartan. Budapest. Akadémiai Kiadó.

Herczig, B. 1983. Harminc éves a magyar fénycsapda hálózat. Növényvédelem 19. (2): 90-94.

Puskás, J., Nowinszky, L. 2008. Pre- and Postfrontal Influences on Light Trapping of Winter Moth (Operophtera brumata L.). Acta Silv. Lign. Hung. Vol. 4 (2008) 49-54.

Jermy, T., Balázs, K. 1993. A növényvédelmi állattan kézikönyve 4/B. Budapest. Akadémiai Kiadó.

Kovács, L. 1962. A növényvédelmi fénycsapdák 1961. évi eredményeiből. 12. Növényvédelmi Tudományos Értekezlet. 135-137.

Nowinszky, L. 2000. Fénycsapdázás. Szombathely. Savaria University Press.

Nowinszky, L. (2003): A fénycsapdázás kézikönyve. Savaria University Press 272.

Nowinszky L., Puskás J. 1998. Light trapping of winter moth (Operophthera brumata L.) at the time of weather fronts. Berzsenyi Dániel Tanárképző Főiskola Tudományos Közleményei Természettudományi Füzetek 2. 4551.

Nowinszky L., Puskás J. 2002. A kis téliaraszoló (Operopthera brumata L.) fénycsapdázása a Péczely-féle makroszinoptikus helyzetek fennállásának időtartamával összefüggésben. Berzsenyi Dániel Főiskola Tudományos Közleményei Természettudományi Füzetek 9. pp. 5-8.

Nowinszky, L., Mészáros, Z., Puskás, J. 2008: The beginning and the end of the insects' flight towards the light according to different environmental lightings. Applied Ecology and Environmental Research, 6(2): 135-143.

Puskás J., Nowinszky L. 1998. A kis téliaraszoló (Operophthera brumata L.) fénycsapdázásának eredményessége időjárási frontok idején. Berzsenyi Dániel Tanárképző Főiskola Tudományos Közleményei XI. Természettudományok 6. Szombathely, 1998. 53-59.

Schwerdtfeger, F. 1969. Ökologie der Tiere-Demökologie. Paul Parey. Hamburg-Berlin

Sipkay, Cs., Horváth, L., Nosek, J., Oertel, N., Vadadi-Fülöp, Cs., Farkas, E., Drégelyi-Kiss, Á., Hufnagel, L. 2008. Analysis Of Climate Change Scenarios Based On Modelling Of The Seasonal Dynamics Of A Danubian Copepod Species - Applied Ecology And Environmental Research, 6(4): 101-109.

Sipkay, Cs., Kiss, K.T., Vadadi-Fülöp, Cs., Hufnagel, L. 2009. Trends In Research On The Possible Effects Of Climate Change Concerning Aquatic Ecosystems With Special Emphasis On The Modelling Approach Applied Ecology And Environmental Research, 7(2): 171-198.

Szabóky, Cs., Csóka Gy. 2008. A püpökladányi Farkassziget lepkéi. Budapest. Erdészeti Tudományos Intézet.

Szontagh, P. 1980. Gradationverhältnisse der eichenschädlicher Geometriden Arten in Ungarn. Prace Muzea V, Hradcy Kralove. 257-259.

Szőcs, G. 1976. A kis téliaraszoló (Operophtera brumata L.) életmódja. Állattani Közlemények. 83. $237-238$.

Tóth, J. 1999. Erdészeti rovartan. Budapest. Agroinform Kiadó. 